\title{
Biologia Futura: rapid diversification and behavioural adaptation of birds in response to Oligocene-Miocene climatic conditions
}

\author{
Jenő Nagy ${ }^{1}$ (D) \\ Received: 25 March 2020 / Accepted: 28 May 2020 / Published online: 4 June 2020 \\ (c) The Author(s) 2020
}

\begin{abstract}
Our knowledge about the origin of landbirds (Telluraves) is increasing rapidly but new questions are arising because of the contradictory findings from previous studies. All of the major lineages in the highly diverse clade of Neoaves have a Gondwanan origin, although studies often disagree about the origin of different sub-lineages. Nevertheless, understanding the biogeographical histories of these groups (e.g. Accipitriformes, Passeriformes) is important when studying the evolution of variation in life history and behavioural traits. Therefore, we would like to find answers to questions such as which biogeographic changes affected the radiation of birds? When did the most influential climatic events affect the diversification of birds? What behavioural adaptations occurred in response to those large-scale changes? The major orogenetic events in Asia and South America formed specific corridors that enabled the radiation of birds. The climatic changes and habitat differentiation they caused during the Oligocene-Miocene era made the divergence of birds possible through their adaptation to newly available niches. Consequently, variation in life history and behavioural traits emerged as adaptive outcomes of changes in foraging, nestling and migratory behaviours.
\end{abstract}

Keywords Accipitriformes $\cdot$ Biogeography $\cdot$ Migration $\cdot$ Passeriformes $\cdot$ Phylogeny $\cdot$ Speciation

\section{Background}

Most of the avian lineages and their closest relatives, which were predominantly arboreal or aquatic taxa, went extinct by 65 million years ago (Mya), around the CretaceousPaleogene boundary (Field et al. 2018). However, the few lineages that survived then rapidly diversified afterwards. Almost all common ancestors of recent lineages appeared by the Late Eocene and the number of species exponentially increased from a hundred to over ten thousands at present (Ksepka and Phillips 2015). The success of birds over geological time frames is the consequence of their rapid ability to adapt when confronted with new climatic, habitat or trophic niches (Pearman et al. 2014; Jønsson et al. 2015; Field et al. 2019). Among terrestrial vertebrates, birds represent one of the 'most mobile' groups in terms of their ability to travel long distances and to cross large geographical and

Jenő Nagy

jenonagy.off@gmail.com

1 Department of Evolutionary Zoology and Human Biology, University of Debrecen, Egyetem tér 1, Debrecen 4032, Hungary ecological barriers (e.g. mountains, deserts, water surfaces). In this sense, the regular, seasonal movements-widely known as migration-are one of the major factors and also typical for a significant proportion $(\sim 15 \%)$ of bird species (Newton 2008). Migration provides opportunities for birds to acquire their energy needs by seeking seasonally available resources in geographically disparate areas (Voskamp et al. 2017; Somveille et al. 2018).

Unfortunately, behavioural traits are not captured in the fossil record which makes it difficult to study their evolution. Our only chance of doing this is to estimate such transitions using data from extant species, whilst controlling for their phylogeny. Although bird remains are poorly fossilized, recent studies have successfully integrated fossil, genetic and morphological data to reconstruct the evolutionary histories of birds (Jetz et al. 2012; Jarvis et al. 2014). All major lineages of modern birds evolved at least 50 Mya which implies that basal divergences occurred shortly after the Cretaceous-Paleogene mass extinction event (Brusatte et al. 2015). The three largest clades (Palaeognathae, Galloanseres, Neoaves) of birds had a West Gondwanan origin at that time (Claramunt and Cracraft 2015) and spread to Australia and Zealandia, and to North America. Therefore, 
core landbirds (Telluraves) originated from South America, whilst oscines (Passeroid clade) had an Australasian ancestor (Claramunt and Cracraft 2015; Oliveros et al. 2019). Consequently, studying the historical biogeography in one of the oldest splits (Accipitriformes) and in the youngest but most specious lineage (Passeriformes) provides possible insights into the early radiation and late diversification within landbirds. However, I will begin by outlining the biogeographical and climatic changes during the Middle Cenozoic.

\section{Major biogeographic events and climatic conditions during the Oligocene- Miocene era}

The geological histories of South and Central Asia, Africa and South America are the most influential in the evolution of landbirds. The collision of the Indian and Southeast Asian land masses started as early as 60-58 Mya (Najman et al. 2010; DeCelles et al. 2014); however, the elevation of the Tibetan Plateau barely exceeded $3000 \mathrm{~m}$ until the Eocene-Oligocene era, when the orogenic processes significantly increased the elevation of this area over $4500 \mathrm{~m}$ (Botsyun et al. 2019). The latitudinal position of the Himalaya-Tibetan Plateau had a great impact on the climate of Central and East Asia (Zhu et al. 2019). Due to its northward migration, the uplifting Himalaya-Tibetan Plateau formed a barrier to water vapour transport, which resulted in the climate in Central Asia becoming increasingly dry and the formation of the monsoon systems in South and East Asia (Clift and Webb 2019; Zhang et al. 2018). Moreover, the uplift of the Tian Shan and Altai mountains in the Late Miocene enhanced the aridization of Central Asia by blocking wet airflows from the west (Xu 1984a, b; Varga 1996; Rugenstein and Chamberlain 2018).

Similarly radical changes in climate also occurred in Africa, where the development of the Ethiopian Plateau and the East African Rift System accelerated during the Oligocene (Chorowicz 2005; Sepulchre et al. 2006). The lower elevation of East and North Africa was associated with higher levels of precipitation, which resulted in climatic conditions that favour the colonization of arboreal vegetation, whilst the increasing elevation during the Oligocene-Miocene era facilitated the aridization of these regions (Ramstein et al. 2019). This led to the emergence of the first savannah/grassland habitats that make up much of the southern African continent today (Sepulchre et al. 2006; Bonnefille 2010; Ramstein et al. 2019).

Moreover, deserts were formed in South America due to climatic changes during the uplift of the Andes. The orogeny of the South American mountain regions occurred in multiple steps (Armijo et al. 2015; Lamb 2016; Garzione et al. 2017) and the formation of the Western Cordillera relief started in the Middle Eocene and that was followed by the slow widening of the whole Andean orogenetic zone. The rapid uplift of the Western and Eastern Cordillera and the Altiplano Plateau occurred within a relatively short time interval during the Late Oligocene-Early Miocene (Lamb 2016; Garzione et al. 2017). These elevational changes coincided with a global decrease in temperatures, first in the Late Eocene and then in the Early Miocene, which caused the aridity and subsequent hyper-aridity of the Atacama Desert (Armijo et al. 2015; Garzione et al. 2017). In addition, the uplift of the Central and Northern Andes reversed the flow of the Amazonas (Sacek 2014), which river is one of the most important components in the water system of South America, influencing a significant part of the vegetation on the continent.

Finally, the development of the Antarctic ice shield and the globally cooling climate during the Middle Miocene also increased the level of aridization in North America, where the emergence of grasslands accelerated due to temporally decreasing levels of precipitation (Flower and Kennett 1994). The uplift of the North American Cordillera also played a key role in the emergence of grasslands and also in the development of glaciers in the Northern Hemisphere in the Pliocene (Ruddiman and Kutzbach 1989; Foster et al. 2010).

At this point, it is important to note that substantial differences drove the evolution of large-scale spatial movements in birds. Some of the above geographical and climatic changes facilitated the movements of birds along and within a latitudinal belt, i.e. within-zonality movements in Eurasia, whilst others formed corridors for north-south or south-north movements, i.e. the direction of mountains in North and South America or the fragmented landscapes (islands) between Australia and mainland Asia.

Therefore, groups that diversified in East and Southeast Asia were frequently distributed along an east-west axis and within-zone (e.g. boreal, mountainous, arid, tropical) migration is more likely to have evolved early (e.g. Dufour et al. 2020). Consequently, the ancestral migratory behaviour established the flexibility for other behavioural changes such as in foraging strategies. Meanwhile, groups that originated in Africa and South America were only able to change more gradually because of the presence of larger ecological barriers towards other continents. Thus, migration evolved more recently, after the emergence of new ecological niches (e.g. Nagy and Tökölyi 2014; Nagy 2019). Afterwards or parallel with the colonization of new areas, north-south migration appeared as secondary adaptations to changing environmental conditions, rather than as a consequence of major adaptations (e.g. foraging, habitat use). I would suggest that these ideas should be tested further, although I would like to show some possible examples for these two hypotheses on the evolution 
of migration, after summarizing the phylogeny and biogeography of two related orders below.

\section{The historical biogeography of Accipitriformes}

The Accipitriformes (Fig. 1) includes New World vultures (Cathartidae), the secretarybird (Sagittariidae), ospreys (Pandionidae) and kites, hawks, and the eagles (Accipitridae) which are divided into eleven subfamilies (Gill et al. 2020). This order is one of the earliest splits within landbirds (Brusatte et al. 2015). Phylogenetic studies reveal that core Accipitriformes are a sister group to the New World vultures (Cathartidae) and these all are more closely related to nocturnal birds of prey (Strigiformes) then to the other diurnal groups of raptors (Falconiformes). Falcons, however, are closely related to parrots (Psittaciformes) and seriemas (Cariamiformes), together forming a sister taxa to Passeriformes (Hackett et al. 2008; Prum et al. 2015).

Although the phylogeny of raptors has been extensively studied, very little comprehensive research has been published. Based on a study of accipitrid birds of prey, including all available gene sequences for two-thirds of the extant species globally, all major lineages have high posterior support ( $>0.93$ ), except for the split between Harpaginae and the superclade of Haliaeetinae and Buteoninae (0.83), for the common ancestor of Accipitrinae (0.61), and for the split between Harpiinae and Aquilinae (0.45, Nagy and Tökölyi 2014; see also Jiang et al. 2015).

The phylogenetic tree in Nagy and Tökölyi (2014) was suitable enough to estimate the historical biogeography of the order. The common ancestor of all of the species was most likely Afrotropical, and all subfamilies have their origin in the Southern Hemisphere (either a single or joint distribution on one or more continents). This suggests that raptor species spread out from Africa to South America (e.g. Perninae, Elaninae, Harpiinae), to Southeast Asia (Circaetinae) and later to Australia (Haliaeetinae) during the Late Oligocene-Middle Miocene (Nagy and Tökölyi 2014).

\section{The origin of Passeriformes}

The global phylogenetic and biogeographic patterns of Passeriformes have been extensively studied and here, I focus on a few of the important studies rather than all of them (Fig. 2). The Passeriformes order has the highest diversity among major avian lineages, comprising more than $60 \%$ of all extant bird species (Oliveros et al. 2019). It is divided into two suborders (Tyranni, Passeri), and two-three parvorders within each suborder (Fig. 3). The larger Passeri (oscines) clade consists at least 10 superfamilies (Claramunt and Cracraft 2015; Mackiewicz et al. 2019; Oliveros et al. 2019).

The Tyranni (suboscines) suborder, which are the common ancestors of all passerine birds have either a South American (Claramunt and Cracraft 2015) or Australasian origin (Oliveros et al. 2019). Meanwhile, the Australian distribution of the common ancestor of all Corvides and Passerides are highly supported (Jønsson and Fjeldså 2006; Fjeldså 2013; Claramunt and Cracraft 2015; Moyle et al. 2016; Kennedy et al. 2017; Oliveros et al. 2019).

The Australasian region remained a diversification hotspot throughout the Middle Oligocene-Early Miocene era

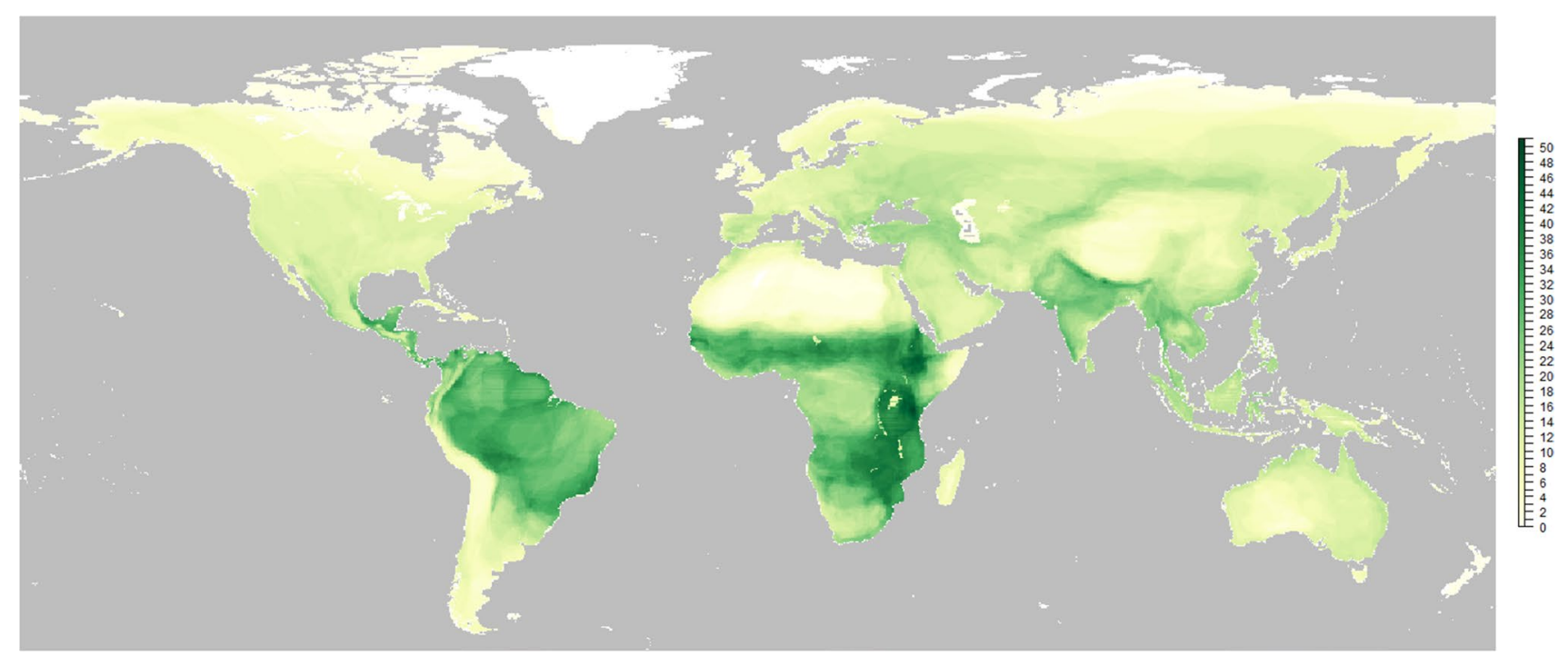

Fig. 1 Diversity map of Accipitriformes (258 species). The colour gradient (from light to dark) indicates species richness 


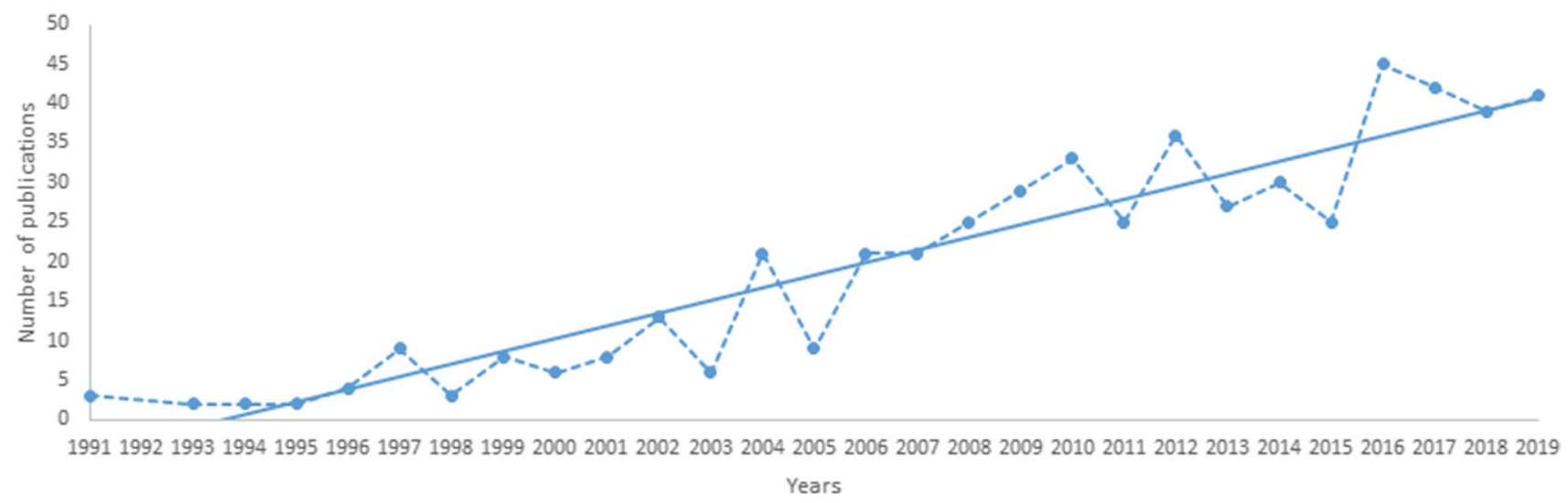

Fig. 2 The number of manuscripts published per year based on a search in the Web of Science database using the 'passeriformes AND phylogeny OR passeriformes AND biogeography' term

(Moyle et al. 2016; Oliveros et al. 2019; but see also Claramunt and Cracraft 2015 for slightly different chronology) until the ancestors of some of the younger clades radiated to Eurasia and Africa. The Emberizoidea superfamily, positioned at the top of the phylogenetic tree, is the only clade to have likely originated in North America (Barker et al. 2015; Oliveros et al. 2019; but see also Moyle et al. 2016).

The common ancestor of the Muscicapoidea and its sister clades originated in the Indomalayan region some 30-20 Mya, and the members of the superfamily radiated to Eurasia (Cibois and Cracraft 2004; Jønsson and Fjeldså 2006; Sangster et al. 2010; Moyle et al. 2016; Oliveros et al. 2019). The Sturnidae has its basal radiation in Southeast Asia, although the Turdidae and the Muscicapidae families show many diversification hotspots in different regions of the world (Fjeldså 2013). The Turdidae most likely originated in Southeast Asia (Nagy 2019) but the most specious subset within the family, the Turdus genus has either a Southeast Asian (Nagy et al. 2019) or European origin (Batista et al. 2020). According to these two studies, Southeast Asia has a cumulative probability of 0.78 (albeit the highest probability for a joint area including Southeast Asia at the root is 0.23, Nagy et al. 2019) and Europe has a probability of around 0.6 (Batista et al. 2020).

Moreover, the global diversity of the Muscicapidae is similar to the Sylviidae (Fig. 3c, e), although the number of species follows a decreasing species-richness gradient towards Europe in Muscicapidae. However, a secondary hotspot can be found in the Mediterranean in Sylviidae. Moreover, the Himalayan-Hengduan mountains as biodiversity hotspots (e.g. Dong et al. 2020) sharply appear in all Passeriformes lineages distributed over that region (Fig. 3). The northern and southern boundaries of the Tibetan Plateau channelize the east-west movements and distributional patterns of several groups in both animals and plants (e.g. Xu 1981; Varga 1996). Therefore, the Central and Southeast
Asian regions played a fundamental role in the origin and radiation of the Passeriformes, especially for Muscicapidae, Sylviidae, Turdidae and Fringillidae.

\section{The evolution of migration in Accipitriformes and in Turdidae}

The phylogeny and biogeographic origin of one of the oldest (Accipitriformes) and one of the youngest (Muscicapoidea: Turdidae) clades within the landbirds was discussed above. A significant number of species follow the strategy of regular seasonal movements, i.e. migration in both groups but it remains unclear where and when that migratory behaviour appeared.

Among accipitrid birds of prey, migration evolved multiple times during the Early Miocene-Holocene era (Nagy and Tökölyi 2014). The evolutionary transitions among the three levels of migratory behaviour (non-migratory, partial, migratory) show that each type of migration evolved directly from non-migratory behaviour, which may reflect the distributional differences of species. The availability of novel habitat types due to the emergence of vast grassland biomes during the Miocene era may have facilitated these behavioural changes. Migration appeared simultaneously with the colonization of subtropical and temperate regions (Nagy and Tökölyi 2014), which is a scenario supported by correlated evolutionary and historical biogeographic patterns within the group. Shifts in breeding distribution, from tropical to non-tropical, more than likely occurred in migratory lineages and the ancestors of most migratory species have tropical origin. These findings support the southern origin of migration alongside the Miocene acceleration of speciation and range expansion in raptors (Nagy and Tökölyi 2014).

In thrushes, meanwhile, migration is an ancestral behaviour in multiple groups, e.g. in Catharus (Voelker et al. 
(A) Passeriformes

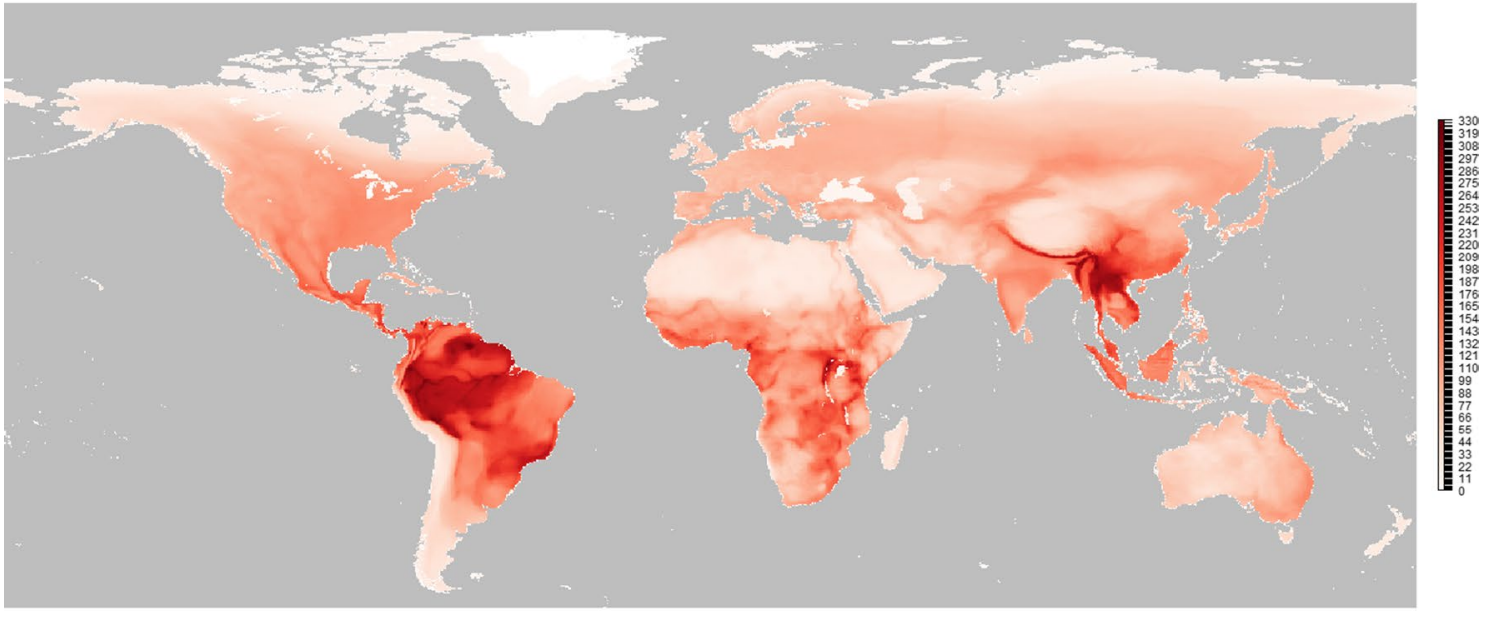

(B) Meliphagidae

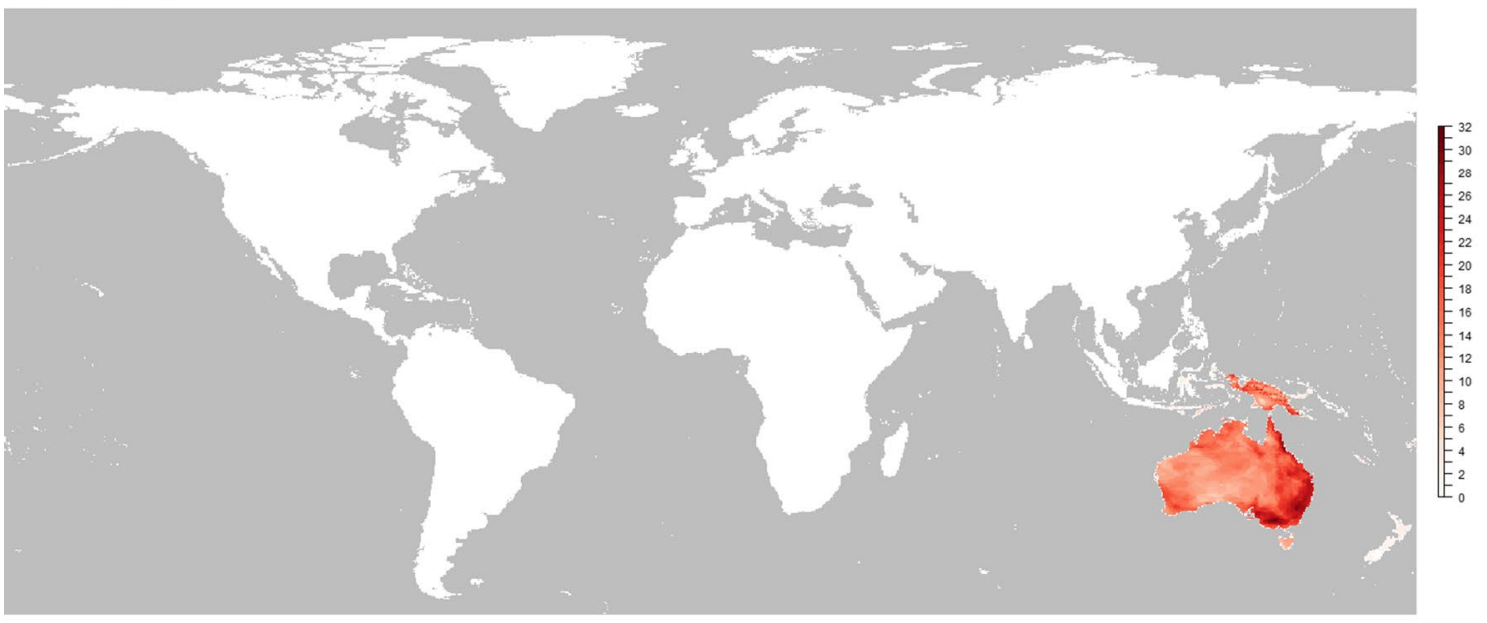

\section{(C) Sylviidae}

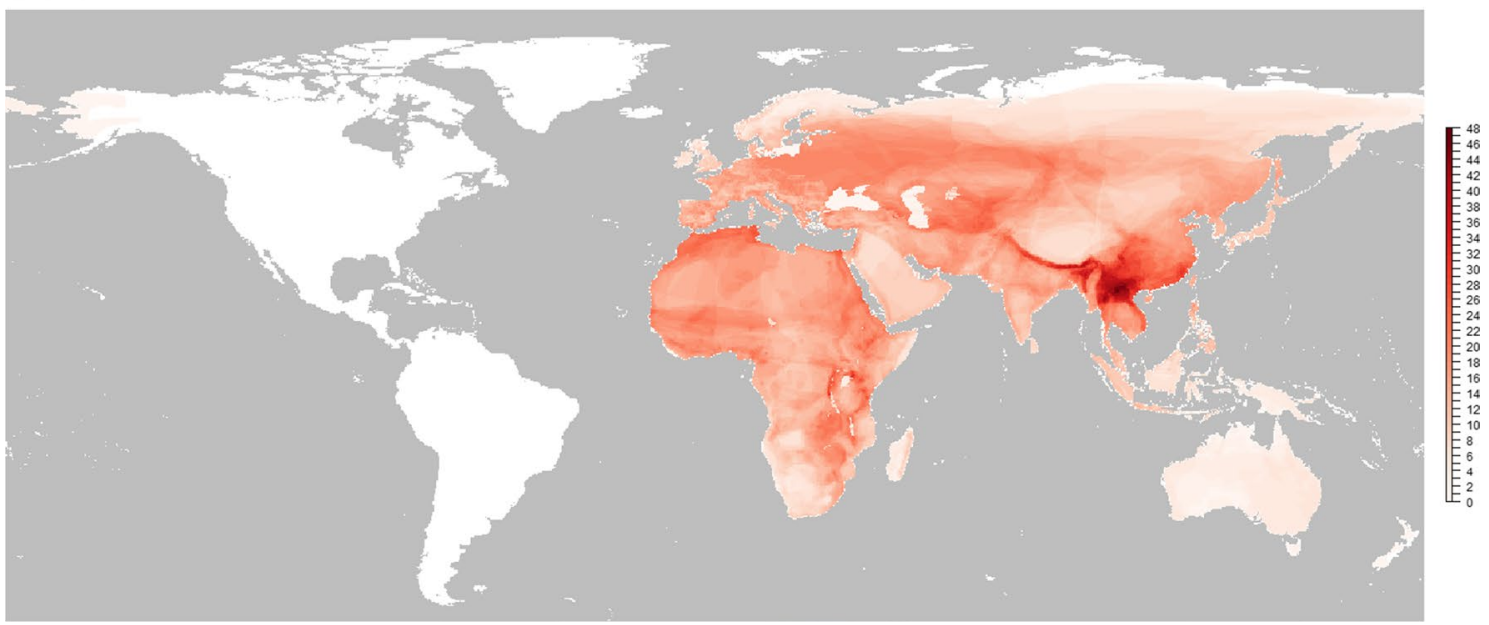

Fig. 3 Diversity maps of Passeriformes. a All Passeriformes (5870 species), and the families consisting $>150$ species: Passeri: b Meliphagidae (177), c Sylviidae (293), d Timaliidae (326), e Muscicapidae (287), f Turdidae (174), g Fringillidae (177), h Emberizidae
(308), i Thraupidae (262); Tyranni: j Thamnophilidae (222), k Furnariidae (243), 1 Tyrannidae (415). The colour gradient (from light to dark) indicates species richness 


\section{(D) Timaliidae}

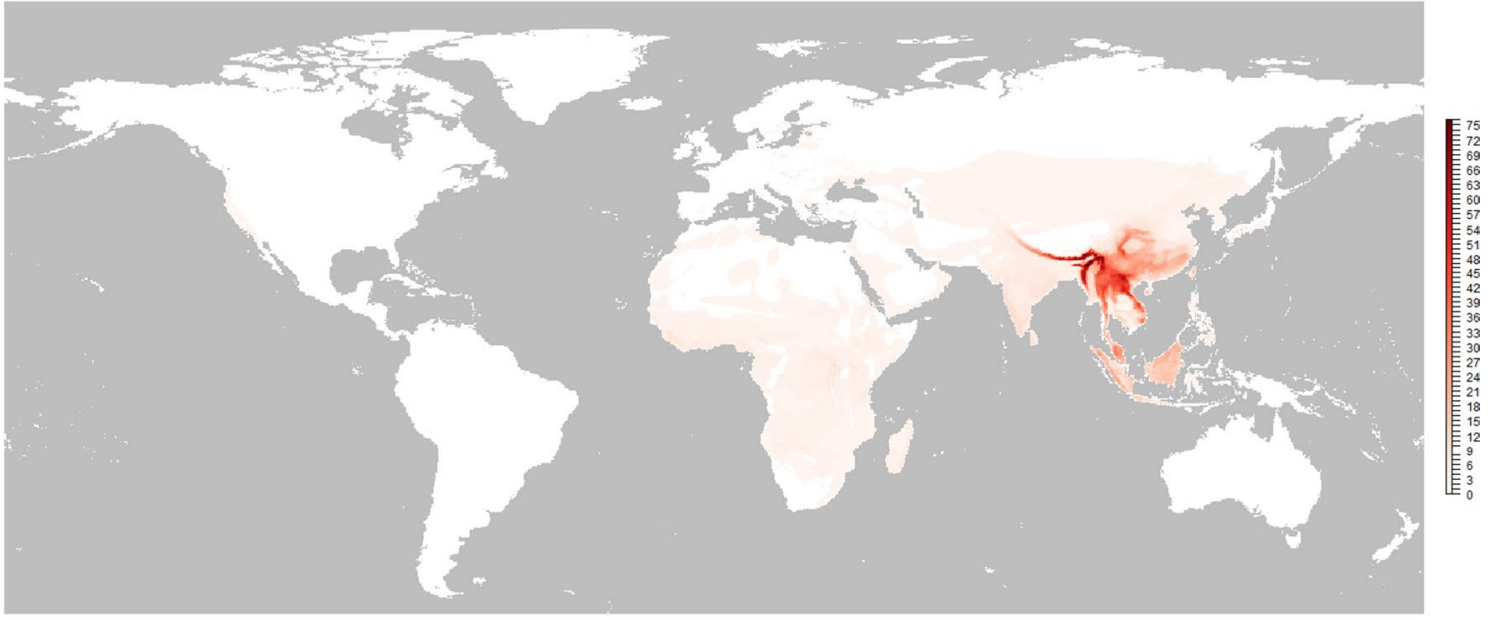

(E) Muscicapidae

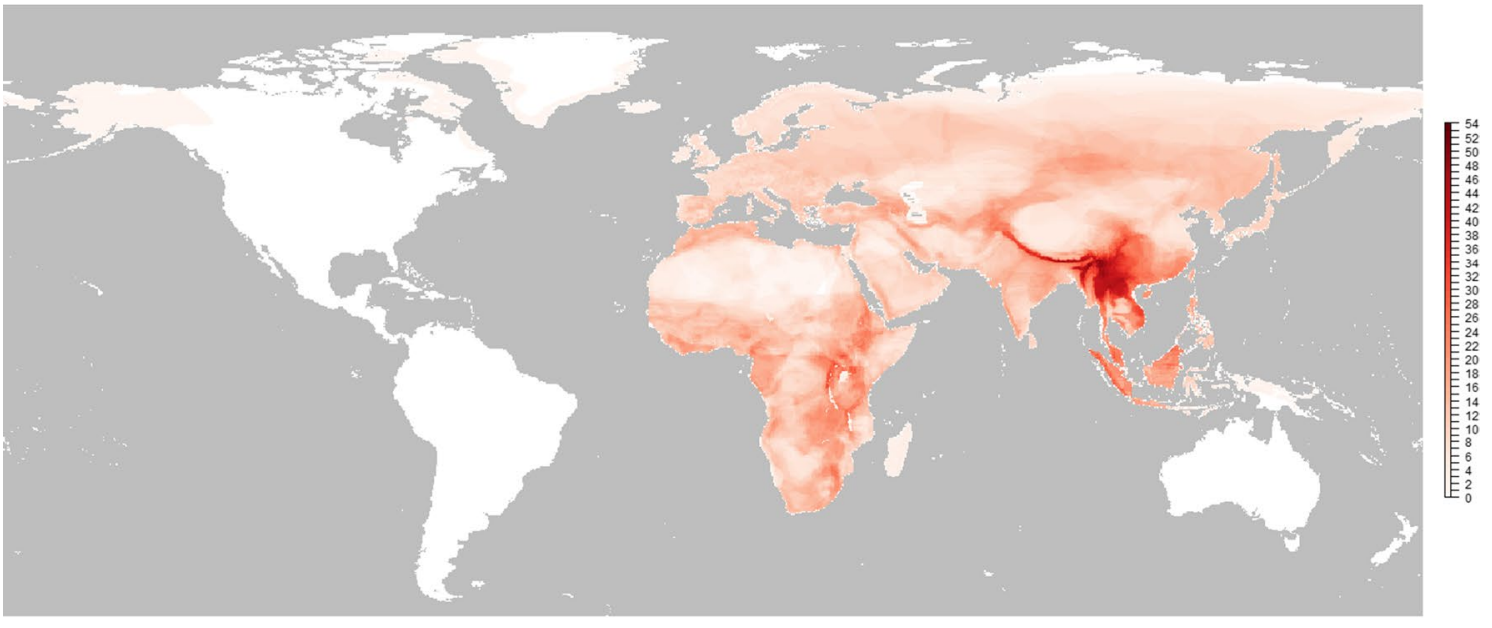

(F) Turdidae

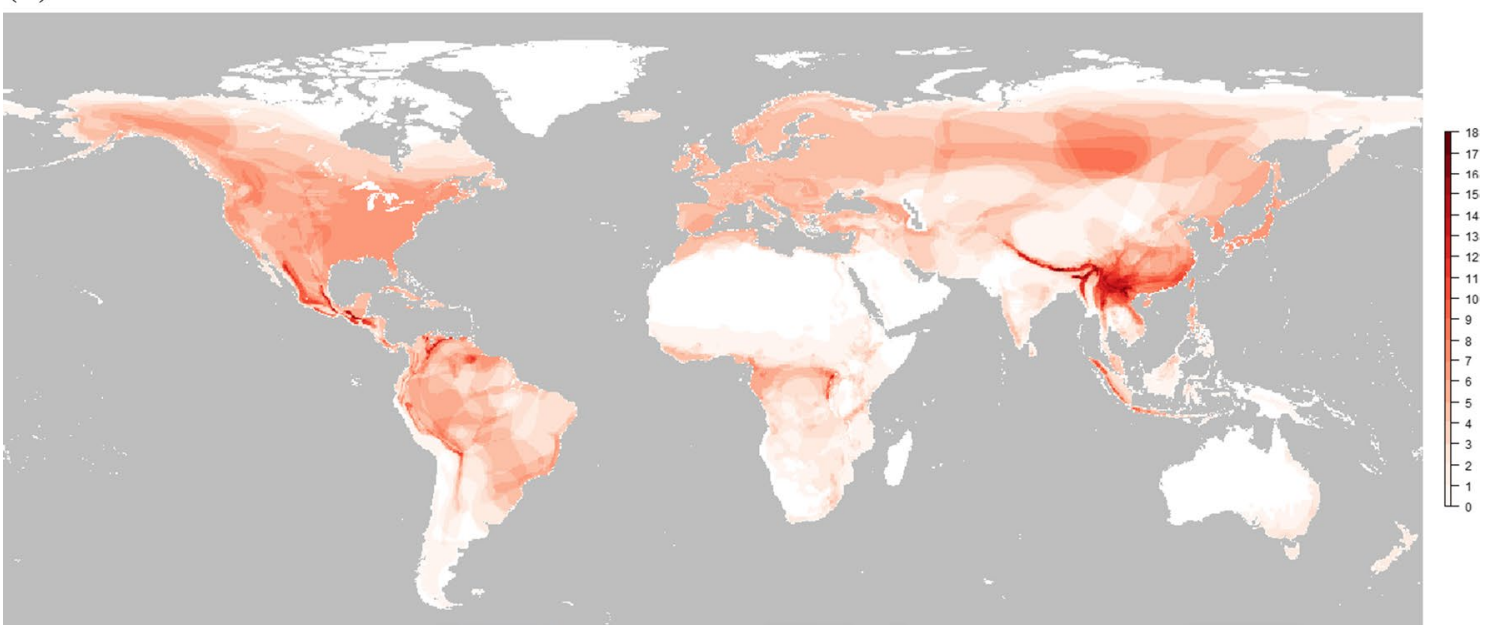

Fig. 3 (continued) 


\section{(G) Fringillidae}

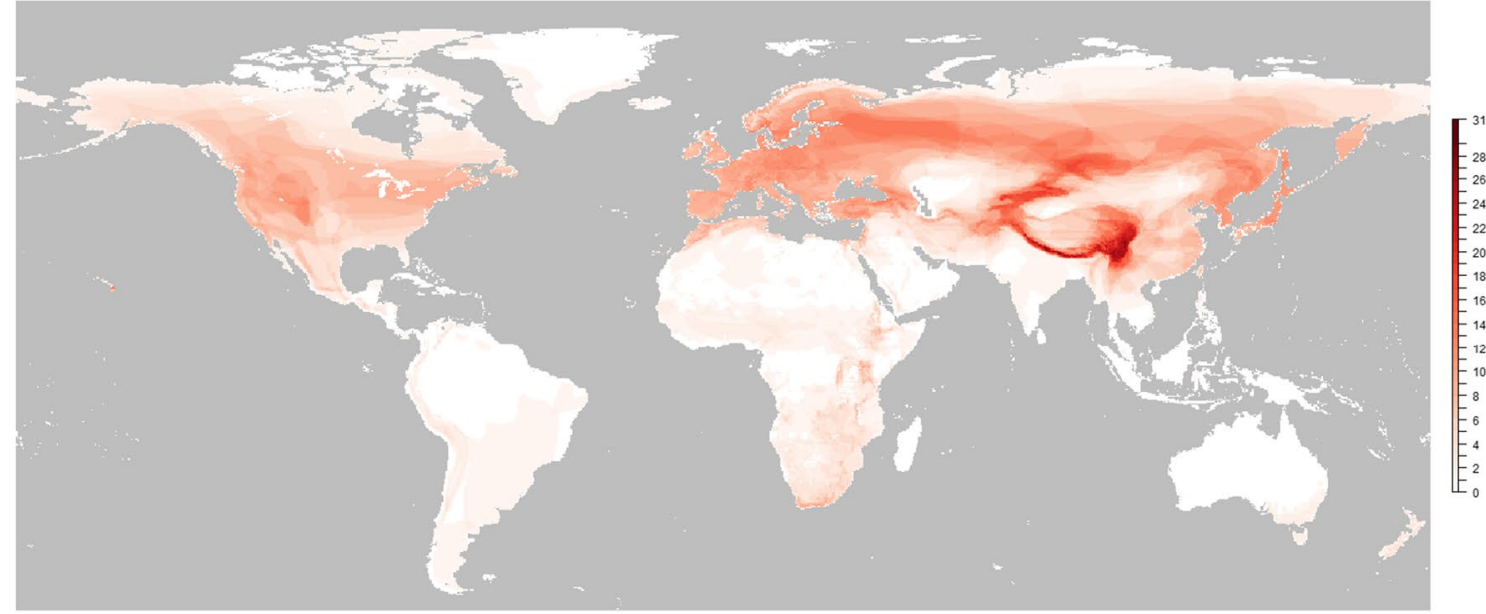

(H) Emberizidae

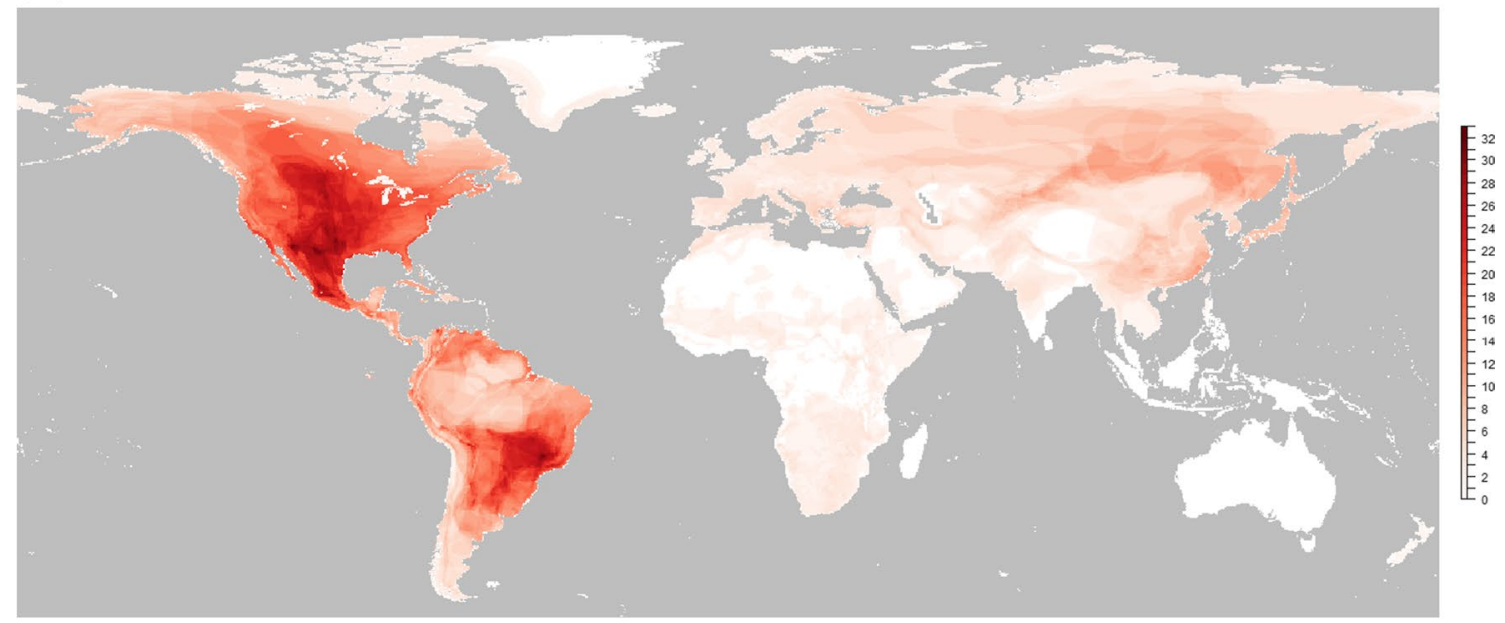

\section{(I) Thraupidae}

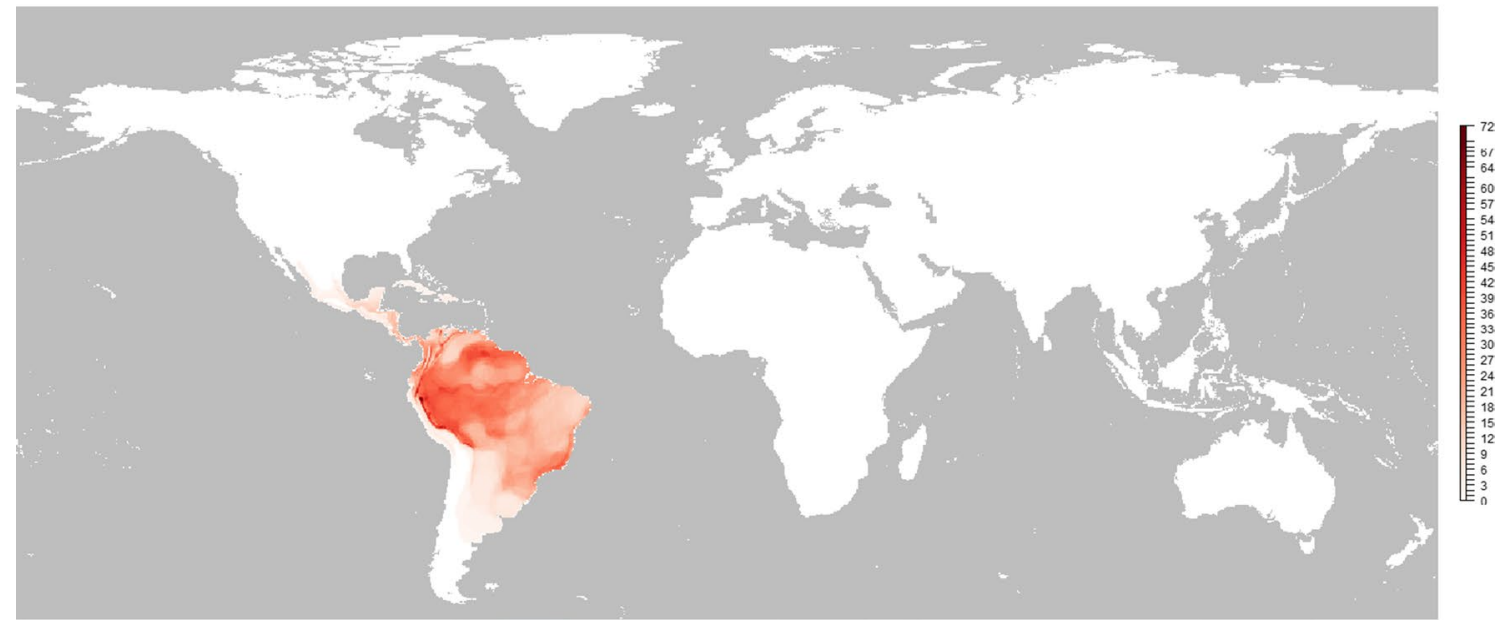

Fig. 3 (continued) 


\section{(J) Thamnophilidae}
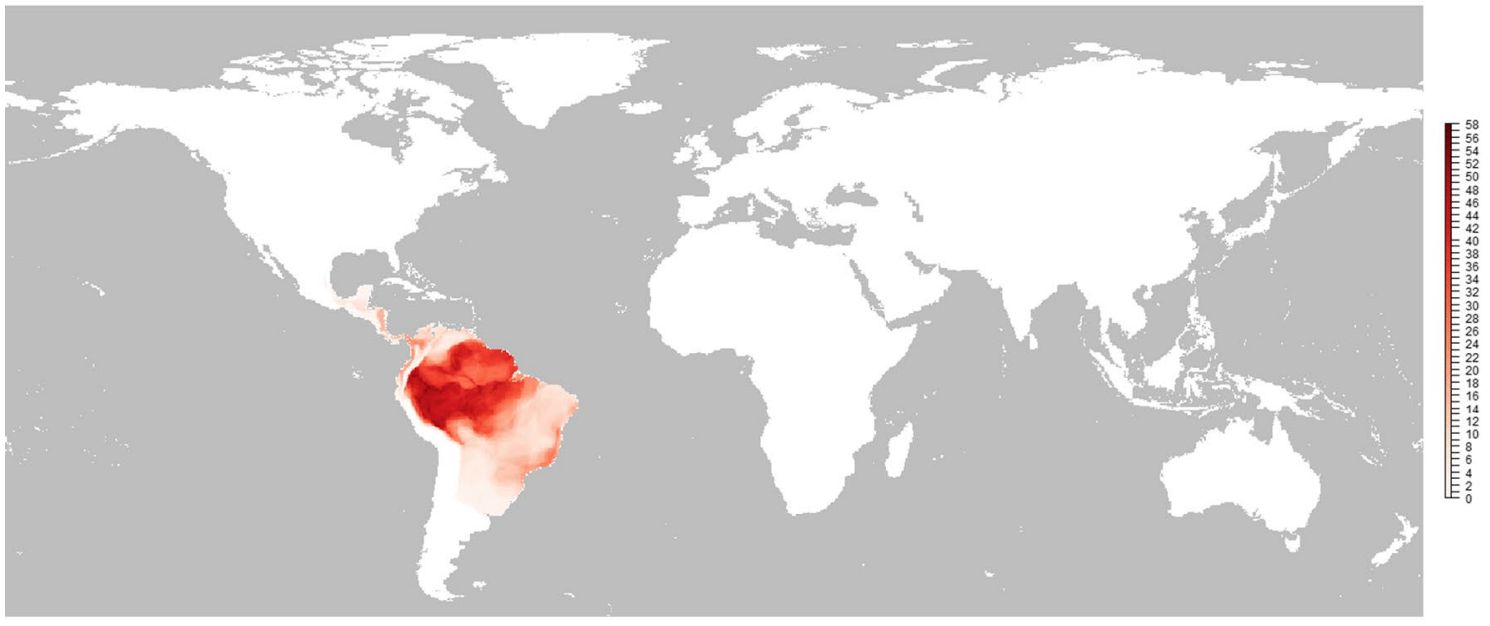

\section{(K) Furnariidae.}

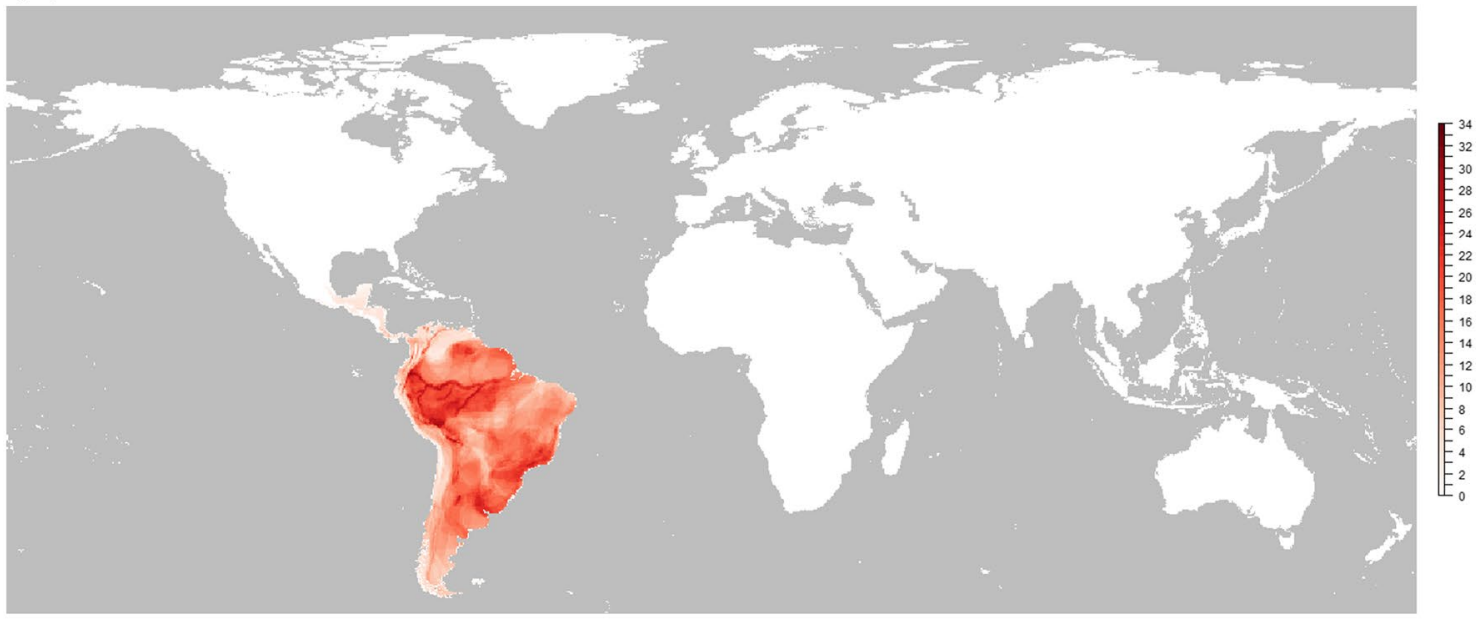

\section{(L) Tyrannidae}

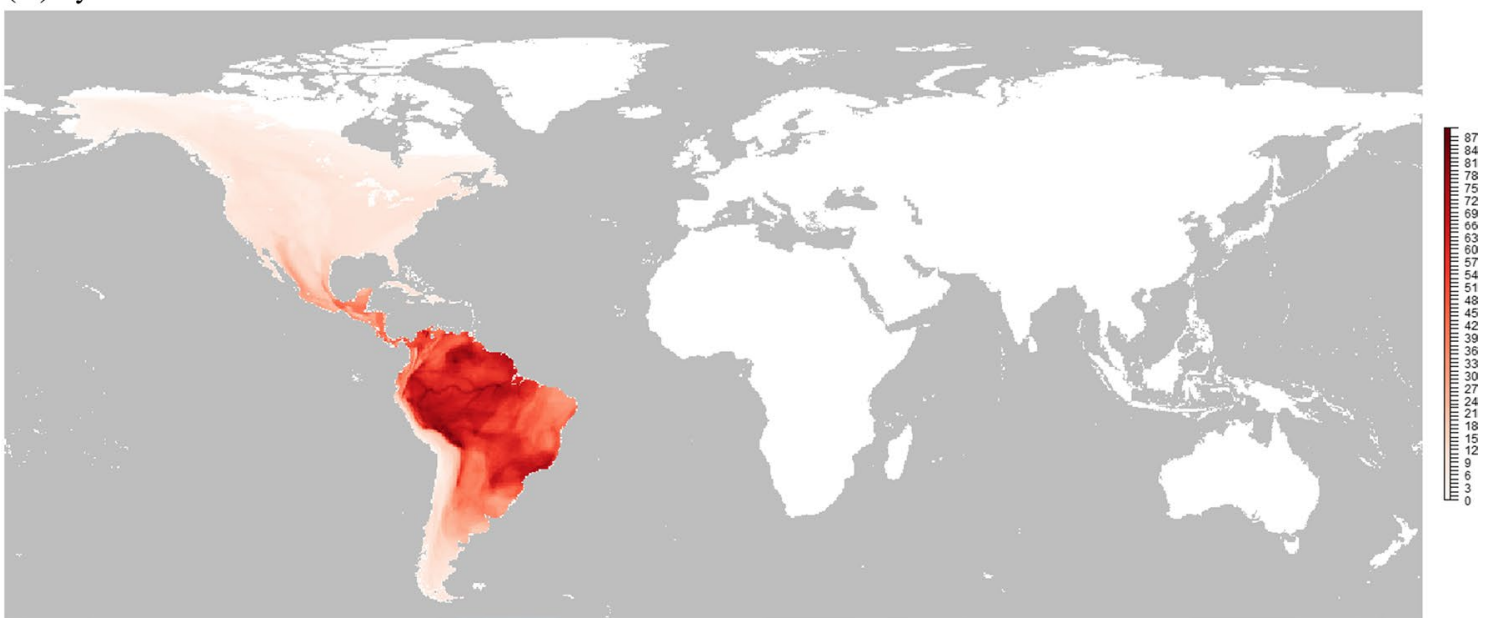

Fig. 3 (continued) 
2013) and in Turdus (Nagy et al. 2019). This pattern is congruent with the findings of a study that examined a broader set of taxa, in which migratory lineages appeared earlier during the evolution of the Passeriformes (Dufour et al. 2020). Similarly to raptors, speciation and rapid radiation also started in Turdidae during the Miocene (Nagy et al. 2019; Nagy 2019). This again supports the idea that the global cooling during the Oligocene as well as the extension of grassy vegetation during the Miocene facilitated diversification and behavioural changes throughout the entire radiation of birds. Migration probably evolved because it provided advantages for passerine birds during periods of rapid changes in climate (Dufour et al. 2020) and it was more likely an ancient behaviour in this species-rich group of birds.

However, the loss of migratory behaviour occurred more frequently in Turdus thrushes and in other passerine families (Nagy et al. 2019), which was in association with the narrowing distribution to tropical areas (including islands) and/ or changes in their foraging behaviour (Nagy et al. 2019; Nagy 2019; Sato et al. 2020). The specialization of diets and meeting energetic demands are two of the key drivers in the evolution of migration in birds (e.g. raptors, Nagy and Tökölyi 2014; thrushes, Nagy et al. 2019; birds, Somveille et al. 2018; Sato et al. 2020).

\section{Contrasting findings and possible ways to deal with them}

In this section, I aim to highlight possible directions for further research. Broad scale biogeographic estimations may suffer from the biased sampling of taxa because for example, all basal and several internal nodes (including the basal ones for Passeriformes) show South American ancestral distributions (Claramunt and Cracraft 2015). However, the most frequent biogeographic realm in the study of Claramunt and Cracraft (2015) is South America, appearing in $46 \%$ of the involved species (105/230) of which $48 \%$ is distributed in South America and one of the other realms (50/105) or exclusively endemic to South America (35/50). The proportion of cosmopolitan species that are distributed in at least five regions is $27 \%(61 / 230)$, which species are also less informative in broad scale biogeographic analyses. Moreover, a significant number of the South American endemic species are basal or represent the earliest splits to the whole taxon set (Fig. 4) and for the Passeriformes as well (Fig. 3i-1). Additionally, alternative estimation methods (only dispersal-vicariance was tested) show a higher degree of uncertainty (see the supplementary information in Claramunt and Cracraft 2015) and unfortunately the authors did not statistically compare the alternative models.
The posterior probabilities for each node of the maximum clade credibility tree are also important in the evaluation of biogeographic models, which are also lacking. Therefore, further analyses on a less biased taxon set comparing multiple models are recommended.

It is therefore unsurprising that in a more recent study, including 209 species of Passeriformes, Australasia was found to be where the common ancestors of the Passeriformes originated (Oliveros et al., 2019). In this study, $14 \%$ of the species (29/209) can be considered as cosmopoli$\tan$ (which I define as being distributed at least 3 out of 5 regions) and the phylogenetic reconstruction shows relatively well-supported results, which is therefore more suitable for ancestral biogeographic estimations. Another issue concerns biogeographic regionalisation, because Oliveros et al. (2019) never just combined the Western and Eastern Palearctic realms, as Claramunt and Cracraft (2015) also did, but they also merged the Indomalayan realm to this, thereby creating a super region covering more than one-third of Earth's total landmass surface. Their results are therefore less informative for the three most specious parvorders, i.e. in the case of the entire Muscicapida and Passerida, and in the half of the Sylviida.

One possible explanation for the conflict between South American versus Australasian origin lies in the position of the biogeographic realms in the past. South America, the non-glaciated Antarctica and Australia were connected during the Eocene, which allowed highly mobile groups such as birds to disperse (Claramunt and Cracraft 2015; Oliveros et al. 2019). Moreover, significant climatic changes occurred between the diversification of basal Passeriformes and the radiations of Passeroid clades and so the choice of the most appropriate taxon sets and the definition of the biogeographic regions for answering the studied questions are very important indeed, and should also be accompanied by analyses that compare the different methods and models used. I suggest that it is not sufficient to sample a selection of species when attempting to draw a larger picture, although it is useful when examining individual parts (e.g. complete genera/families) in detail and then compiling them all together.

How important the used taxon sets are, the case of Turdus thrushes is a good example for it. A comparative analysis of 72 thrush species showed that Southeast Asia and/or Africa were the most likely ancestral region for the group (Nagy et al. 2019) before Turdus species spread out to Europe and South America during the middle stages of the Miocene. In contrast, Batista et al. (2020) found that the genus originated in the Western Palearctic and colonized Africa and the Antilles at around the time of the Miocene-Pliocene boundary and reached South America not earlier than 5 Mya.

Although both studies used comprehensive genetic datasets, neither was able to produce a fully supported 


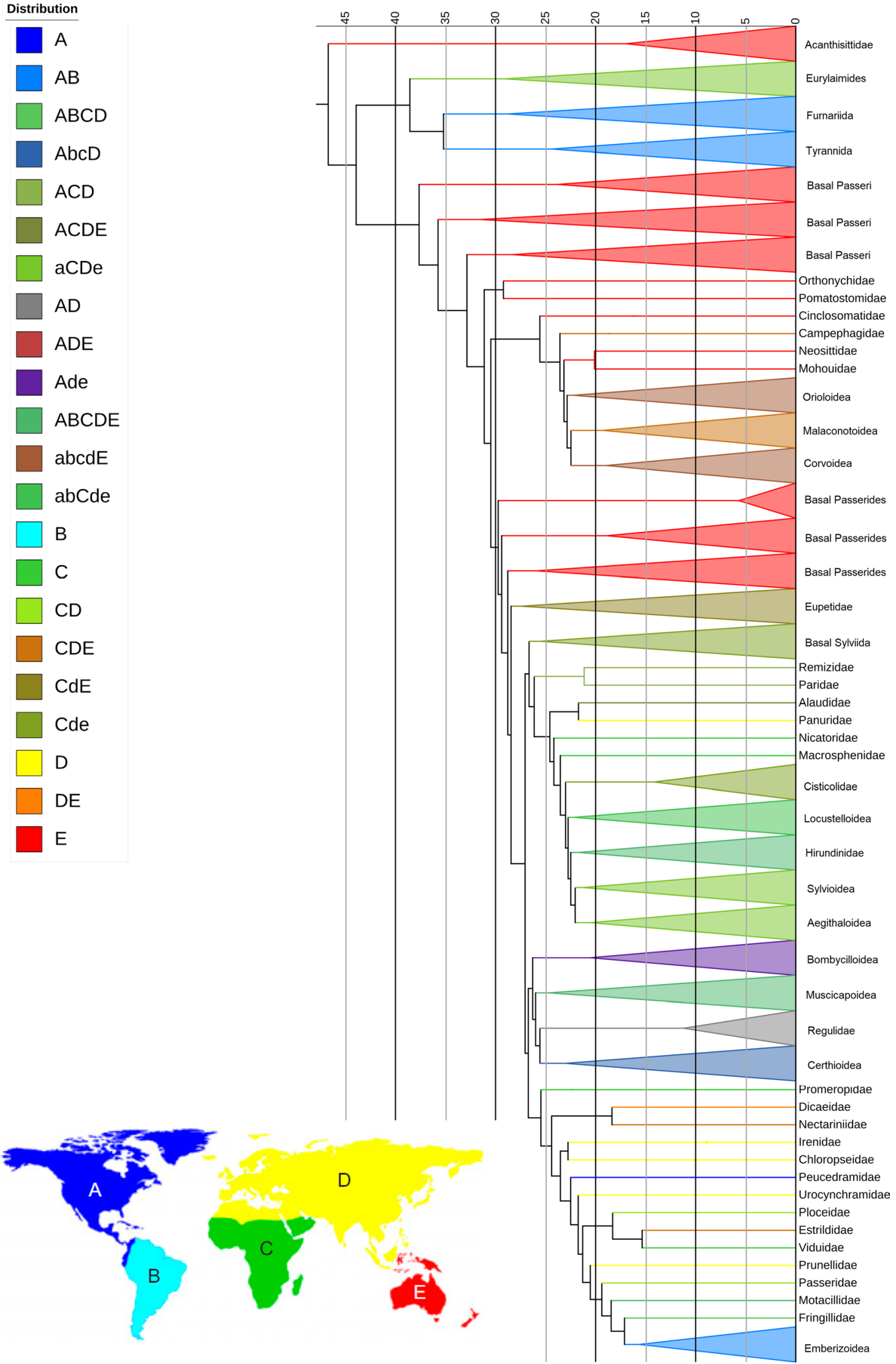


४Fig. 4 Simplified phylogenetic tree of Passeriformes. The backbone tree topology and the biogeographic regionalization correspond to Oliveros et al. (2019) and thus, the map in the bottom left corner was transcribed from their original publication. The abbreviations in the legend refer to the appropriate regions on the map. Multiple letters indicate multiple regions, where upper case letters indicate dominant regions in the distribution of species. Timescale (Mya) is at the top and triangles indicate multiple branches collapsed at the original topology and have no additional information content

phylogenetic tree. The different evolutionary histories of the different genes could have affected the phylogenetic hypotheses (e.g. Reddy et al. 2017; Nagy 2017). Further research involving the entire family and the comparison of different phylogenetic and biogeographic hypotheses is still needed because it would help clarify the origin, pattern of radiation and the association with migratory behaviour in the family (Nagy 2019 and the references therein).

\section{Conclusions for future biology}

In this review, I aimed to highlight some topical points and highlight fruitful areas which most warrant further research.

The historical biogeographic patterns in one of the oldest orders within Neoaves (which is basal in Telluraves), together with examples from one of the youngest radiations (Passeriformes) seem to support the idea that Africa and Australasia was the likely place of origin for these birds. However, South America is rather one of the earliest destinations during the radiation of landbirds than the origin of the basal lineages. Even so, the centre of the asteroid impact, which caused the last largest mass extinction on Earth at the Cretaceous-Paleogene boundary, was located in South America although the tropical (Gondwanan) origin of landbirds is supported by the histories of both Accipitriformes and Passeriformes.

The climatic changes during the Oligocene-Miocene era caused differentiation in the zonality of vegetation types. The aridization and the emergence of vast savannah grasslands made it possible to occupy newly available niches that also in turn facilitated the rapid speciation and radiation of birds. Two major patterns emerge: first, the colonization of both subtropical and temperate regions as demonstrated in Accipitriformes, and second, a within zonal radiation (probably in an east-west direction) as shown in Turdus thrushes, but possibly generally in Passeriformes more broadly. In raptors, those Miocene climatic changes discussed are associated with behavioural changes, i.e. the appearance of migration, whilst, the already existing, inherited migratory behaviour intensified the diversification of Passeriformes. These might also be good explanations for the significant differences in species richness among orders. However, it is worth noting that the major orogenetic events in Eurasia and then in America only had a minor influence on the origin of Accipitriformes are considered to be far more relevant for the Passeriformes.

Additionally, the evolution of migratory and foraging strategies are highly associated with one another. Migration could evolve on more generalist lineages or on lineages with the ability to show flexibility in terms of their food sources, although geographic limitations (e.g. islands, (dis)continuity of distribution areas) could lead to the loss of migratory behaviour.

In general, a more comprehensive study on a well-defined group may provide insights that are not possible using less well-defined groups. Therefore, it is recommended that appropriate taxon sets and biogeographic regions are clearly defined for these kinds of studies. Finally, the comparison of alternative hypotheses and models is also a worthy endeavour when evaluating competing explanations.

Acknowledgements Open access funding provided by University of Debrecen (DE). I am grateful to Ádám Miklósi who invited me to write this review and to Zoltán Varga for his useful comments on an earlier version of the manuscript. I would also like to express my gratitude to Mark C. Mainwaring for revising the language.

\section{Compliance with ethical standards}

Conflict of interest I have no competing interests.

Open Access This article is licensed under a Creative Commons Attribution 4.0 International License, which permits use, sharing, adaptation, distribution and reproduction in any medium or format, as long as you give appropriate credit to the original author(s) and the source, provide a link to the Creative Commons licence, and indicate if changes were made. The images or other third party material in this article are included in the article's Creative Commons licence, unless indicated otherwise in a credit line to the material. If material is not included in the article's Creative Commons licence and your intended use is not permitted by statutory regulation or exceeds the permitted use, you will need to obtain permission directly from the copyright holder. To view a copy of this licence, visit http://creativecommons.org/licenses/by/4.0/.

\section{References}

Armijo R, Lacassin R, Coudurier-Curveur A, Carrizo D (2015) Coupled tectonic evolution of Andean orogeny and global climate. Earth Sci Rev 143:1-35

Barker FK, Burns KJ, Klicka J, Lanyon SM, Lovette IJ (2015) New insights into new world biogeography: an integrated view from the phylogeny of blackbirds, cardinals, sparrows, tanagers, warblers, and allies. Auk 132:333-348

Batista R, Olsson U, Andermann T, Aleixo A, Ribas CC, Antonelli A (2020) Phylogenomics and biogeography of the world's thrushes (Aves, Turdus): new evidence for a more parsimonious evolutionary history. Proc R Soc B 287:20192400

Bonnefille R (2010) Cenozoic vegetation, climate changes and hominid evolution in tropical Africa. Glob Planet Change 72:390-411 
Botsyun S, Sepulchre P, Donnadieu Y, Risi C, Licht A, Rugenstein JKC (2019) Revised paleoaltimetry data show low Tibetan Plateau elevation during the Eocene. Science 363:eaaq1436

Brusatte SL, O'Connor JK, Jarvis ED (2015) The origin and diversification of birds. Curr Biol 25:R888-R898

Chorowicz J (2005) The East African rift system. J Afr Earth Sci 43:379-410

Cibois A, Cracraft J (2004) Assessing the passerine "Tapestry": phylogenetic relationships of the Muscicapoidea inferred from nuclear DNA sequences. Mol Phylogenet Evol 32:264-273

Claramunt S, Cracraft J (2015) A new time tree reveals Earth history's imprint on the evolution of modern birds. Sci Adv 1:e1501005

Clift PD, Webb AAG (2019) A history of the Asian monsoon and its interactions with solid Earth tectonics in Cenozoic South Asia. In: Treloar PJ, Searle MP (eds) Himalayan tectonics: a modern synthesis. The Geological Society of London, London, pp 631-652

DeCelles PG, Kapp P, Gehrels GE, Ding L (2014) Paleocene-Eocene foreland basin evolution in the Himalaya of southern Tibet and Nepal: implications for the age of initial India-Asia collision. Tectonics 33:824-849

Dong F, Hung CM, Yang XJ (2020) Secondary contact after allopatric divergence explains avian speciation and high species diversity in the Himalayan-Hengduan Mountains. Mol Phylogenet Evol 143:106671

Dufour P, Descamps S, Chantepie S, Renaud J, Guéguen M, Schiffers $\mathrm{K}$, Thuiller W, Lavergne S (2020) Reconstructing the geographic and climatic origins of long-distance bird migrations. J Biogeogr 47:155-166

Field DJ, Bercovici A, Berv JS, Dunn R, Fastovsky DE, Lyson TR, Vajda V, Gauthier JA (2018) Early evolution of modern birds structured by global forest collapse at the end-Cretaceous mass extinction. Curr Biol 28:1825-1831

Field DJ, Berv JS, Hsiang AY, Lanfear R, Landis MJ, Dornburg A (2019) Timing the extant avian radiation: the rise of modern birds, and the importance of modeling molecular rate variation. PeerJ $7: \mathrm{e} 27521$

Fjeldså J (2013) The global diversification of songbirds (Oscines) and the build-up of the Sino-Himalayan diversity hotspot. Chin Birds 4:132-143

Flower BP, Kennett JP (1994) The middle Miocene climatic transition: East Antarctic ice sheet development, deep ocean circulation and global carbon cycling. Palaeogeogr Palaeoclimatol Palaeoecol 108:537-555

Foster GL, Lunt DJ, Parrish RR (2010) Mountain uplift and the glaciation of North America-a sensitivity study. Clim Past 6:707-717

Garzione CN, McQuarrie N, Perez ND, Ehlers TA, Beck SL, Kar N, Eichelberger N, Chapman AD, Ward KM, Ducea MN, Lease RO, Poulsen CJ, Wagner LS, Saylor JE, Zandt G, Horton BK (2017) Tectonic evolution of the Central Andean plateau and implications for the growth of plateaus. Annu Rev Earth Planet Sci 45:529-559

Gill F, Donsker D, Rasmussen P (2020) IOC World Bird List (v10.1). https://doi.org/10.14344/ioc.ml.10.1

Hackett SJ, Kimball RT, Reddy S, Bowie RCK, Braun EL, Braun MJ, Chojnowski JL, Cox WA, Han K-L, Harshman J, Huddleston CJ, Marks BD, Miglia KJ, Moore WS, Sheldon FH, Steadman DW, Witt CC, Yuri T (2008) A phylogenomic study of birds reveals their evolutionary history. Science 320:1763-1768

Jarvis ED, Mirarab S, Aberer AJ, Li B, Houde P, Li C, Ho SJW, Faircloth BC, Nabholz B, Howard JT, Suh A, Weber CC, da Fonseca RR, Li J, Zhang F, Li H, Zhou L, Narula N, Liu L, Ganapathy G, Boussau B, Bayzid MdS, Zavidovych V, Subramanian S, Gabaldón T, Capella-Gutiérrez S, Huerta-Cepas J, Rekepalli B, Munch K, Schierup M, Lindow B, Warren WC, Ray D, Green RE, Bruford MW, Zhan X, Dixon A, Li S, Li N, Huang Y, Derryberry EP, Bertelsen MF, Sheldon FH, Brumfield RT, Mello CV, Lovell PV, Wirthlin M, Schneider MPC, Prosdocimi F, Samaniego
JA, Velazquez AMV, Alfaro-Núñez A, Campos PF, Petersen B, Sicheritz-Ponten T, Pas A, Bailey T, Scofield P, Bunce M, Lambert DM, Zhou Q, Perelman P, Driskell AC, Shapiro B, Xiong Z, Zeng Y, Liu S, Li Z, Liu B, Wu K, Xiao J, Yinqi X, Zheng Q, Zhang Y, Yang H, Wang J, Smeds L, Rheindt FE, Braun M, Fjeldså J, Orlando L, Barker FK, Jønsson KA, Johnson W, Koepfli K, O'Brien S, Haussler D, Ryder OA, Rahbek C, Willerslev E, Graves GR, Glenn TC, McCormack J, Burt D, Ellegren H, Alström P, Edwards SV, Stamatakis A, Mindell DP, Cracraft J, Braun EL, Warnow T, Jun W, Gilbert MTP, Zhang G (2014) Whole-genome analyses resolve early branches in the tree of life of modern birds. Science 346:1320-1331

Jetz W, Thomas GH, Joy JB, Hartmann K, Mooers AO (2012) The global diversity of birds in space and time. Nature 491:444-448

Jiang L, Chen J, Wang P, Ren Q, Yuan J, Qian C, Hua X, Guo Z, Zhang L, Yang J, Wang Y, Zhang Q, Ding H, Bi D, Zhang Z, Wang Q, Chen D, Kan X (2015) The mitochondrial genomes of Aquila fasciata and Buteo lagopus (Aves, Accipitriformes): sequence, structure and phylogenetic analyses. PLoS ONE 10:e0136297

Jønsson KA, Fjeldså J (2006) Determining biogeographical patterns of dispersal and diversification in oscine passerine birds in Australia, Southeast Asia and Africa. J Biogeogr 33:1155-1165

Jønsson KA, Lessard JP, Ricklefs RE (2015) The evolution of morphological diversity in continental assemblages of passerine birds. Evolution 69:879-889

Kennedy JD, Borregaard MK, Jønsson KA, Holt B, Fjeldså J, Rahbek C (2017) Does the colonization of new biogeographic regions influence the diversification and accumulation of clade richness among the Corvides (Aves: Passeriformes)? Evolution 71:38-50

Ksepka DT, Phillips MJ (2015) Avian diversification patterns across the K-Pg boundary: influence of calibrations, datasets, and model misspecification. Ann Mol Bot Gard 100:300-328

Lamb S (2016) Cenozoic uplift of the Central Andes in northern Chile and Bolivia-reconciling paleoaltimetry with the geological evolution. Can J Earth Sci 53:1227-1245

Mackiewicz P, Urantówka AD, Kroczak A, Mackiewicz D (2019) Resolving phylogenetic relationships within Passeriformes based on mitochondrial genes and inferring the evolution of their mitogenomes in terms of duplications. Genome Biol Evol 11:2824-2849

Moyle RG, Oliveros CH, Andersen MJ, Hosner PA, Benz BW, Manthey JD, Travers SL, Brown RM, Faircloth BC (2016) Tectonic collision and uplift of Wallacea triggered the global songbird radiation. Nat Commun 7:12709

Nagy J (2017) Phylogeny and evolution of the European Goldfinch (Carduelis carduelis) and its allies-a review of the "bird of the year". Ornis Hung 25:1-10

Nagy J (2019) Interactions of climate, migration and life history traits in the evolutionary history of birds. Ph.D. thesis. Debreceni Egyetem, Debrecen

Nagy J, Tökölyi J (2014) Phylogeny, historical biogeography and the evolution of migration in accipitrid birds of prey (Aves: Accipitriformes). Ornis Hung 22:15-35

Nagy J, Végvári Z, Varga Z (2019) Phylogeny, migration and life history: filling the gaps in the origin and biogeography of the Turdus thrushes. J Ornithol 160:529-543

Najman Y, Appel E, Boudagher-Fadel M, Bown P, Carter A, Garzanti E, Godin L, Han J, Liebke U, Oliver G, Parrish R, Vezzoli G (2010) Timing of India-Asia collision: geological, biostratigraphic, and palaeomagnetic constraints. J Geophys Res Solid Earth 115:B12416

Newton I (2008) The migration ecology of birds. Academic Press, London

Oliveros CH, Field DJ, Ksepka DT, Barker FK, Aleixo A, Andersen MJ, Alström P, Benz BW, Braun EL, Braun MJ, Bravo GA, Brumfield RT, Chesser RT, Claramunt S, Cracraft J, Cuervo 
AM, Derryberry EP, Glenn TC, Harvey MG, Hosner PA, Joseph L, Kimball RT, Mack AL, Miskelly CM, Peterson AT, Robbins MB, Sheldon FH, Silveira LF, Smith BT, White ND, Moyle RG, Faircloth BC (2019) Earth history and the passerine superradiation. PNAS 116:7916-7925

Pearman PB, Lavergne S, Roquet C, Wüest R, Zimmermann NE, Thuiller W (2014) Phylogenetic patterns of climatic, habitat and trophic niches in a European avian assemblage. Glob Ecol Biogeogr 23:414-424

Prum RO, Berv JS, Dornburg A, Field DJ, Townsend JP, Lemmon EM, Lemmon AR (2015) A comprehensive phylogeny of birds (Aves) using targeted next-generation DNA sequencing. Nature 526:569-573

Ramstein G, Godderis Y, Donnadieu Y, Sepulchre P, Fluteau F, Zhang Z, Zhang R, Su B, Jiang D, Schuster M, Besse J (2019) Some illustrations of large tectonically driven climate changes in Earth history. Tectonics 38:4454-4464

Reddy S, Kimball RT, Pandey A, Hosner PA, Braun MJ, Hackett SJ, Han KL, Harshman J, Huddleston C, Kingston S, Marks BD, Miglia KJ, Moore WS, Sheldon FH, Witt CC, Yuri T, Braun EL (2017) Why do phylogenomic data sets yield conflicting trees? Data type influences the avian tree of life more than taxon sampling. Syst Biol 66:857-879

Ruddiman WF, Kutzbach JE (1989) Forcing of late Cenozoic Northern Hemisphere climate by plateau uplift in southern Asia and the American West. J Geophys Res Atmos 94:18409-18427

Rugenstein JKC, Chamberlain CP (2018) The evolution of hydroclimate in Asia over the Cenozoic: a stable-isotope perspective. Earth Sci Rev 185:1129-1156

Sacek V (2014) Drainage reversal of the Amazon River due to the coupling of surface and lithospheric processes. Earth Planet Sci Lett 401:301-312

Sangster G, Alström P, Forsmark E, Olsson U (2010) Multi-locus phylogenetic analysis of Old World chats and flycatchers reveals extensive paraphyly at family, subfamily and genus level (Aves: Muscicapidae). Mol Phylogenet Evol 57:380-392
Sato E, Kusumoto B, Şekercioğlu ÇH, Kubota Y, Murakami M (2020) The influence of ecological traits and environmental factors on the co-occurrence patterns of birds on islands worldwide. Ecol Res 35:394-404

Sepulchre P, Ramstein G, Fluteau F, Schuster M, Tiercelin J-J, Brunet M (2006) Tectonic uplift and Eastern Africa aridification. Science 313:1419-1423

Somveille M, Rodrigues ASL, Manica A (2018) Energy efficiency drives the global seasonal distribution of birds. Nat Ecol Evol 2:962-969

Varga Z (1996) Biogeography and evolution of oreal Lepidoptera in the Palaearctic. Acta Zool Acad Sci Hung 42:289-330

Voelker G, Bowie RC, Klicka J (2013) Gene trees, species trees and E arth history combine to shed light on the evolution of migration in a model avian system. Mol Ecol 22:3333-3344

Voskamp A, Baker DJ, Stephens PA, Valdes PJ, Willis SG (2017) Global patterns in the divergence between phylogenetic diversity and species richness in terrestrial birds. J Biogeogr 44:709-721

Xu R (1981) Vegetational changes in the past and the uplift of QinghaiXizang Plateau. In: Xu R (ed) Geological and ecological studies of Qinghai-Xizang Plateau. Science Press, Beijing, pp 139-144

Xu R (1984a) Changes of the palaeoenvironment of Southern East Asia since the late Tertiary. In: Whyte RO (ed) The evolution of the East Asian environment. University Press, Hong Kong, pp 419-425

Xu R (1984b) Changes of the vegetation in China since the late Tertiary. In: Whyte RO (ed) The evolution of the East Asian environment. University Press, Hong Kong, pp 426-432

Zhang R, Jiang D, Ramstein G, Zhang Z, Lippert PC, Yu E (2018) Changes in Tibetan Plateau latitude as an important factor for understanding East Asian climate since the Eocene: a modeling study. Earth Planet Sci Lett 484:295-308

Zhu C, Meng J, Hu Y, Wang C, Zhang J (2019) East-Central Asian climate evolved with the northward migration of the high protoTibetan Plateau. Geophys Res Lett 46:8397-8406 